\title{
The Utilization of Colonial Historical Sites in the City of Palembang as a Learning Resource Based on Outdoor Learning
}

\author{
$\underline{\text { Riki Andi Saputro }}$ \\ Universitas Sebelas Maret Surakarta, Indonesia \\ Email: rikiandisaputra33@gmail.com
}

\begin{abstract}
The activeness of all students' senses can occur if students participate actively in learning activities. One of the learning activities that are able to actively involve students is by the way of outdoor learning. Research sub-focus: Cultural Heritage and Colonial Historical Sites. The formulation of the problem in this study: Historical value in the colonial period sites in the city of Palembang. The purpose of this research is to provide resource that can be used in learning History in High School. The benefit of this research is the availability of source and references for writing the history of the colonial period in Palembang. This research used history (historical) method, assisted by scientific approach from various fields (multi-approach) such as theological, political, anthropological and sociological sciences. The results of the research on colonial historical sites in the city of Palembang contain as a source of learning based on outdoor learning in high school.
\end{abstract}

Keywords: outdoor learning; colonial historical site

\section{Introduction}

History subject are important subject that instill knowledge, values and insight into the Indonesian. The nation and state of Indonesia is a large country, which has a long history from pre-historic times to historical times. As an important subject in school, history is taught from Elementary School to College. History subject at the Elementary and Junior High School levels are included in Social Science subjects. In High School, history subjects are taught as compulsory subject and history of specialization (Ni'mah, K: 2015).

History education learning is history learning that is able to activate all the senses in learning activities and is not boring. He activeness of all students' senses can occur if students participate active in learning activities. One of the learning activities that can active involve students is by way of outdoor learning (Nisa: 2015). This outdoor learning activity is a learning activity that takes place in the classroom and outside the classroom by utilizing the potential in the environment around students. History learning is one of the lessons that has a great opportunity to package field-based learning or the use of historical objects. Because there are objects or historical sites scattered in the community, especially for sites that are in the form of buildings or which are not possible to be moved into museum such as colonial heritage buildings in Palembang (Saputro et al: 2020). Utilization of historical sites as learning resources with learning activities that involve active the student participation can make history learning interesting (Rahman: 2017). Because so far the general paradigm condemns learning history as one of the lesson that is considered boring because the presentation of material is too past to be reached (Nurhasanah et al: 2010). The name Palembang comes from the regional languages which consists of two words, namely pa and limbang. Pa means place and limbang means melimbang or "separate gold from water and earth". 
According to folklore, one of the sources of livelihood for the people of Palembang at that time was panning for gold from the Tatang river (Saputro et al: 2020). However, in the Malay language, pa has the meaning of place and lembang which means low soil in water, depressed soil, swollen roots, and soft because of long submerged in water, dripping or coiling water. This understanding fits with the geographical conditions of Palembang to date, which is a city located on low land and generally flooded. The name Palembang recorded in history has appeared since the Srivijaya era, because the name Palembang in the writings of a Chinese author, Chau Ji Kau in his book Chu Fan Chai. He mention Palembang's name as Po-lin Fong. A person from Portugal named Tomi Pires in the early 16th century called Palembang Palimbam. Palembang city is listed as the oldest city in Indonesia. The Kedukan Bukit inscription is a sign of the founding of the city, the capital of the Sriwijaya kingdom. The Sriwijaya Kingdom was a maritime kingdom that had a larges naval fleet (Sholeh: 2018).

The city of Palembang had quite a lot of history and cultural which is divided into the Sriwijaya Period, Majapahit Period, Early Sultanate Period, Sultanate Period, Columial Period, Japanese Period, Independence Period (Contemporary) and Toponym. By knowing the meaning of history and culture in Palembang, it is hoped that the younger generation will awaken the spirit of patriotism, like their ancestors in the past (Saputro et al: 2020). Protect, utilize, historical and cultural resources of Palembang. The history and culture of Palembang can be used as a supplement for learning history. Not only presented in the classroom through learning media, but we invited students to come down directly to the field where history exists and learn directly on the spot. With activities like this, it is certainly more interesting in the learning process (Sulistyo: 2019). The basis of this learning is outdoor learning. Takes place outside the classroom by visiting historical places from the colonial era in the city of Palembang. Although in this study the sample is the history of the colonial era, but there is still much more historical history in the city of Palembang that can be used as a source of historical learning according to its period. Such as the Sriwijaya Period, the Majapahit Period, the Early Sultanate Period, the Sultanate Period, the Colonial Period, the Japanese Period, the Independence Period (Contemporary) and Toponyms.

Learning directly by visiting historical and cultural sites in Palembang is expected to be an alternative solution for learning history. Student activities in learning activities here through observation, exploration and discussion activities together are able to activate all senses (Anwar: 2009). Not only hear and see but also do directly. One thing that is an important appeal is that if an area has a historical site or is included in cultural heritage objects then the history should be used as the main learning source for history learning (Awantara: 2020). Therefore, in this study, the author has an idea that hopes to again provide encouragement for history teachers to created fun history learning. One of the solutions proposed by researchers is the used of history that is around us. As a context in this idea is a historical site in the city of Palembang. Therefore, the title of this research is the Utilization of Colonial Historical Sites in Palembang City as a Source of Learning-Bases outdor learning.

\section{Research Methods}

This research used the historical (historical) method, assist by scientific approach from various fields (multi-apraach) such as theological, political, anthropological and sociological sciences. The steps of the historical method in this research are the first, source collection (heuristics). In this study, research collected historical sources in the form of primary research books, library research, documents, books and journals resulting from general reports that were relevant to the research title. Second, verification (Source criticism). 
In external criticism, the researcher tests whether the source is genuine or not by selecting a simple physical aspect of the source found. In this internal criticism, the researcher criticizes the content of the source regard the authenticity of the source content, such as identifying the informant or the author of the book/document, whether the writing or reporting of the source is correct, rational and logical by looking at the existing facts and other theories.

Third, Interpretation. In this step, after critical readings of historical sources have been carried out, a description of the synthesis put forward by several experts in their theories and facts is carried out, then after that they are described and then linked a fact with other facts so that it can be analyzed correctly and properly. The last, History Writing (Historiography). As the last phase in the historical method is historiography which means the way of writing, presenting, or reporting the results of historical research that has been carried out by researchers (Alian: 2012).

\section{Discussion}

\subsection{Historical Relics of the Colonial Period in Palembang City a. GPIB I mmanuel Church/Chicken Church}

GPIB Immanuel Church is located at Jalan P.A.K. Abdul Rohim No. 1 Village Rt. 28/ Rw. 12 Kelurahan 29 Ilir, Ilir Barat II Subdistrict, Palembang City, South Sumatra Province. Position coordinates at: S 02 ${ }^{\circ} 9^{\prime} 31.1^{\prime \prime}$ E 104 $45^{\prime} 08.9^{\prime \prime}$. Immanuel Church is a Protestant Christian Church, Immanuel means child of God. This church has a fair large yard with accompanying buildings in the form of a pastor's house, a church caretaker's house, and a meeting hall (Field observation notes no. 5).

Immanuel Church is called the chicken church because at the top of the church tower there is a rooster-shaped signpost. The spire decoration is a rural architectural tradition in Germany as a form of cardinal direction, formerly located in a European settlement that was built in the 20th century. The existence of the Immanuel Church building cannot be separated from the work of Dutch zending (evangelists) who came to the city of Palembang from the 19 th century AD. Based on information, the zending had started working in the $1830 \mathrm{~s}$, start with a Dutchman named Ds. Heinrich Julius Berger. He is one of the pioneers or elders (presbyters) in the work of evangelists. This was continued by a Belanda priest named Ds. Barends Johannes Ovink who had come for the first time to Palembang on March 11, 1848. The work of Belanda zending in the city of Palembang was continued by Belanda priests from time to time. At first GPIB in Indonesia had the name "De Protestantse Kerk in Westelijk Indonesie" which was founded on October 31, 1948. Before being independent, GPIB was part of the Indische Kerk/GPI (Indonesian Protestant Church). It is not known for certain the year the church building was built GPIB Immanuel Palembang. It is estimated that the church was founded after the work of the Belanda zending had started in the early 20th century.

According with the growth and development of colonial settlements in the Talang Semut area (Jambi Archaeological Heritage Preservation Center, South Sumatra, Bengkulu and Bangka Belitung Islands. 2016: 41, 42, 43).

\section{b. Plumbing Office}

Jalan Merdeka Mayor Building No. 2 Kampung RT 1 RW 01 Kelurahan 22 Ilir, West Ilir District I, Palembang City, South Sumatra Province, with coordinates: S 02'59'27.2" E 1042445'24.0". With the northern boundary: Jalan Merdeka, East: Jalan Rumah Bari, South: Balai Prajurit, West: Jalan Sekanak (Field observation notes no.6). 
The history of the construction of the mayor's building is known from 1929 to 1930 during the reign of the India and Belanda by the mayor of J. Le Cocq de Armand d'ville. This news about the construction of the mayor's building cost a ton of gold. The mayor's building was designed by a Belanda architect, Ir. S. Snuijf, who at that time lived in the city of Surabaya. This building has an initial function as a clean water reservoir for the residents of Palembang, especially for the Belanda who live around the building. This Mayor's Building has a distinctive colonial architectural characteristic that is often founded in other colonial buildings in the archipelago. The architecture of the mayor's building was built in a style the name is De stijl. The architectural style of this building is influenced by the shape of a cube and has the characteristics of a square base shape and a flat roof. The mayor's building is a multi-storey building and is quite majestic among other buildings, this can be seen from the 35 meters high building and able to accommodate as much as 12,000 $\mathrm{m}$ of water. At the front there are 6 pillars that stand on a pedestal made of cement. On the face or front of the walls are composed of natural stone (andesite). The front view of the building has 3 doors. The shape of this door is double leafed and given an iron trellis. At the front of this building has a faade in the form of box-shaped columns stretching from top to bottom and there are windows decorated with stained glass (Jambi Archaeological Heritage Preservation Center, South Sumatra, Bengkulu and Bangka Belitung Islands. 2016:56-57).

\section{c. Sultan Mahmud Badaruddin II Museum}

Sultan Mahmud Badaruddin II Museum, Jalan Sultan Mahmud Badaruddin II No. 2 Kelurahan 16 Ilir, Ilir Barat II District, Palembang City, South Sumatra Province. The period of this building is the Colonial period in the early 19th century AD. Coordinates: S 02 $59^{\prime} 25.8^{\prime \prime}$ E 104'45'40.3". Bordered by the North: Jalan Merdeka, Tugu Perjuangan, East: Jalan Sudirman, South: Jalan Gede Ing Suro, Musi River, West: Jalan Sultan Mahmud Badaruddin II, Kuto Besak Fort (Notes from field observations no.7).

The background of the establishment of the Sultan Mahmud Badaruddin II museum is inseparable from the historical chronology of the Palembang Darussalam Sultanate. This is because the location or place where the museum building stands which is now a former imperial palace or known as Kraton Kuto Besak. The chronology begins in 1821 AD Kuto Besak palace was attacked by the Belanda until it was destroyed. The incident occurred during the I.L. van Seivenhoven ruled Palembang. Two years ago after the destruction of Kuto Besak palace, in 1823, in the same location, a residence or house was built and occupied by I.L. van Seivenhoven (Archaeological Heritage Preservation Center Jambi, South Sumatra, Bengkulu and the Bangka Belitung Islands. 2016:64).

The Sultan Mahmud Badaruddin II Museum building has an India architecture form. The shapes of the Indis building is a mixture of local and European architecture. This can be seen from the shape of the roof of the museum building which is in the form of a shield or pyramid similar to the roof of a traditional Palembang house (bari house). While the European architectural style can be seen from the front facade with curved shapes on the 1 st floor and the pillars that support the roof on the 2 nd floor. At this times the former home of I.L. van Seivenhoven is used as the office of the Culture and Tourism Office of the City of Palembang on the 1 st floor and the Sultan Mahmud Badaruddin II Museum on the 2nd floor. room divider (Archaeological Heritage Preservation Center Jambi, South Sumatra, Bengkulu and Bangka Belitung Islands. 2016:65).

\section{d. Texstile Museum}

Textile Museum Jalan Merdeka, Talang Semut Village, Bukit Kecil District, Palembang City, South Sumatra Province, with coordinates position: S02 ${ }^{\circ} 59^{\prime} 23.7^{\prime \prime}$ E 104²44'58.3". North 
Border: Mosque, East: Wahidin Street, South: Merdeka Street, West: Diponegoro Street (Notes from field observations no.8).

The Textile Museum building was built by Belanda East India government in 1883. At the beginning of its establishment, the building functioned as a residence for Dutch Resident officials. This is in accordance with the shape of the building as a house that is quite magnificent standing among other house buildings. In accordance with the changing conditions, after Belanda government left Indonesia, this building was taken over by the Indonesian government. After 1945, Indonesian government used this building for various functions. Among other things in 1960 it was used as the Office of the Inspectorate of Justice, changed to the Office of the High Prosecutor, the house where members of the DPRD level I lived, the Office of the Assistant Governor, BP 7 and Research and Development Office and now the Textile Museum (Notes on the results of field observations no. 9).

The description of the Textile Museum building has De Stilj architecture characteristics that are generall found in the early 19th century AD. This building has a rectangular floor plan and a fairly large yard. The hallmark of this former Dutch Resident's building is the porch which is supported by 2 pilasters on either side. Both of these pilasters are rectangular in shapes and there are decorative squares around the pillars. Above the porch is closed with a wall that is given 3 rectangular vents decorated with wooden blinds panels. In addition, on the roof of the house there is an addition such as a chimney (louvre) totaling 1 piece (Jambi Archaeological Heritage Preservation Center, South Sumatra, Bengkulu and Bangka Belitung Islands. 2016:68-69).

\section{2 Outdoor Learning Activities by utilizing colonial sites in Palembang City}

According to Rosmiati (2020) historical sites are learning resources that can use outdoor learning models. Outdoor learning model is able to hone student creativity in lectures, foster a spirit of independence, cooperation between students, train to control emotions and foster scientific attitudes suitable for use in historical sites. Warsino in Rizqi (2020) believes learning local history can increase a sense of concern and interest in their regional areas, to explore more deeply about anything that is on the past trajectory in their area. History learning is carried out in the field by giving projects to students through exploration of objects and sites. For application in learning, it can be implemented in grade 10 and grade 11 for the history of specialization. Grade ten on basic competence 3.2 understand the concept of change and sustainability in history and for eleventh graders with specialization in basic competencies. 3.7 Analyzing the influence of Western imperialism and colonialism in Indonesia in the political, economic, socio-cultural, educational and religious fields as well as the resistance of the Indonesian kingdom to Western imperialism and colonialism (Sandika et al: 2018).

The purpose for the tenth grade regarding KD 3.2 by inviting students directly to the field and showing directly from the existence of historical sites can provide a concrete picture and direct experience related to the material taught in school (Lestari: 2011). This material is also provided with insight into historical sources, whether tangible or not. Historical site buildings which are included in cultural heritage objects are material manifestations of historical sources. Students can use it as a learning resource and research resource to increase their knowledge. Seeing and learning directly from the learning activities they do, the active involvement of the students' senses can function. It is hoped that with activities like this, the learning objectives will be more effectively achieved. For the eleventh grade, the focus is on basic competencies 3.7 with the coverage of teaching materials on Western colonialism in Indonesia. Students can be shown directly the effects of colonialism in the socio-cultural field. 
Historical facts will be more balanced and proportional if they are presented holistically from various points of view. Showing students about colonial heritage sites in the city of Palembang, South Sumatra, shows that the colonial government in addition to its colonial practices also carried out various other activities in various fields (Saputro et al: 2020).

New insights are embedded in students about the sustainability aspects of the buildings that are historical sites. This direct learning experience in the field can give a complete pictures to students in addition to the material taught in the classroom by the teacher. For more details regarding the structure of its activities regarding outdoor learning activities by utilizing colonial sites in the city of Palembang. Schematic of learning activities for the use of historical sites. The smooth running of learning is determined by the preparation of lesson plans in a good and structured scheme. From learning that occurs in the field or learning outside the classroom. The place covers an area in which there are historical sites. In this scheme, it is a core activity in learning (Hermawan et al: 2020), In the three stages above, students must participate actively starting from paying attention to learning orientation, forming a learning group or team, conducting historical exploration, sharing information/knowledge from field findings to reflection activities together with the teacher. In each stage in this learning activity, the teacher only acts as a facilitator and motivator. The teacher facilitates by bringing students to the site location, which must have coordinated with the manager or owner to permit the use of the site for learning activities. The teacher motivates students by providing introductory material that is a stimulus for further exploration by students. Henceforth, in each stage of learning, it is the students who move actively. They activate all their senses in exploration activities, from searching, observing, interviewing to documentation on each of these sites according to their respective learning teams. Through learning activities like this, it will certainly make students happy, with this pleasure they will enjoy learning. As a consequence, learning objectives will be achieved well, students' understanding of the cultural heritage that exists in their environment and its sustainability aspects will be consciously owned by them. Students' understanding of the socio-cultural impact of the practice of colonialism in the archipelago with them exploring colonial sites and building their own knowledge from their experiences (Fernanda: 2018).

This learning activity is one of the alternative solutions to the problem of history learning, which has been known as classroom learning with a lot of boring material. The use of local historical sites around, which in this paper are historical sites of colonialism in the city of Palembang with an outdoor learning approach, is able to arouse students' interest in learning history (Sulistiyo: 2019).

\section{Conclusion}

The activeness of all students' senses can occur if students participate actively in learning activities. One of the learning activities that can actively involve students is by way of outdoor learning. History learning is carried out in the field by giving projects to students through exploration of objects and sites. Utilization of local historical sites that are around, historical sites of colonialism in the city of Palembang with an outdoor learning approach are able to arouse students' interest in learning history.

\section{References}

Alian, A. (2012). Metodologi Sejarah dan Implementasi dalam Penelitian. Jurnal Pendidikan dan Kajian Sejarah (Criksetra), 2(2).

Anwar, K. (2009). Potensi wisata budaya situs sejarah peninggalan Kerajaan Majapahit di 
Trowulan Mojokerto.

Awantara, M. E. (2020). Pemanfaatan Situs-Situs Sejarah di Pati sebagai Sumber Belajar dalam Pembelajaran Sejarah pada SMA Negeri di Kabupaten Pati (Doctoral Dissertation, Universitas Negeri Semarang).

Balai Pelestarian Peninggalan Purbakala Jambi, Sumsel, Bengkulu dan Kepulauan Bangka Belitung. 2016:56-57

Fernanda, T. (2018). Pengembangan Bahan Ajar Sejarah Sistem Pemerintahan Kolonial di Karesidenan Palembang Berbasis Problem Based Learning Untuk Meningkatkan Kemampuan Eksplanasi Sejarah Siswa Kelas XI IPS di SMAN 1 Lawang Kidul (Doctoral dissertation, UNS (Sebelas Maret University)).

Hermawan, W., Idris, M., \& Chairunisa, E. D. (2020). Cagar Budaya Di Palembang Ilir Timur sebagai Sumber Penulisan Buku Saku Sejarah di Palembang. Kalpataru: Jurnal Sejarah dan Pembelajaran Sejarah, 6(1), 53-62.

Lestari, I. D. (2011). Efektifitas Pemanfaatan Situs-situs Sejarah di Banjarnegara sebagai Sumber Belajar dalam Pembelajaran Sejarah pada SMAN 1 Banjarnegara dan SMAN 1 Bawang (Doctoral Dissertation, Universitas Negeri Semarang).

Ni'mah, K. (2015). Penerapan Metode Pembelajaran Role Playing untuk meningkatkan Keaktifan Belajar Siswa pada mata pelajaran Sejarah kelas X IIS 3 MAN Kediri 2 Kota Kediri (Doctoral dissertation, Universitas Islam Negeri Maulana Malik Ibrahim).

Nisa, J. (2015). Outdoor Learning sebagai Metode Pembelajaran IPS dalam Menumbuhkan Karakter Peduli Lingkungan. Sosio-Didaktika: Social Science Education Journal, 2(1), $1-11$.

Nurhasanah, S., \& Guna, S. (2010). Penerapan Model Pembelajaran Kooperatif Tipe STAD untuk Meningkatkan Pemahaman Peristiwa Proklamasi Indonesia dalam Pelajaran Social Science pada Siswa Kelas V SD Negeri 01 Pereng, Karanganyar, Tahun Pelajaran 2009/2010. Skripsi Sarjana Tidak Diterbitkan. Surakarta: FKIP UMS [Fakultas Keguruan dan Ilmu Pendidikan, Universitas Muhammadiyah Surakarta].

Rahman, A. (2017). Pemanfaatan Situs Sejarah sebagai Sumber Belajar di MA Alma'arif Singosari Kabupaten Malang (Doctoral dissertation, Universitas Islam Negeri Maulana Malik Ibrahim).

Rizqi, Y.F., Djono, and Susanto. (2020). Development of Local History Learning with the Heroism Theme of K. Gholib Based on E-Book for Private Vocational School Students in Pringsewu Regency. Budapest International Research and Critics in Linguistics and Education (BirLE) Journal Vol 3 (3): 1287-1300.

Rosmiati, Wahyuni, A., and Syarifuddin, A. (2020). Ombilin Coal Mine Site: History and Potential as a Learning Source for the History of the Economy Based on Outdoor Learning. Budapest International Research and Critics in Linguistics and Education (BirLE) Journal Vol 3 (3): 1343-1352.

Sandika, U. D., \& Wuryani, E. (2018, May). Nilai-Nilai Perjuangan Mangkunagara I dalam Pembelajaran Sejarah (Kajian Babad Pakunagara). In Seminar Nasional Hardiknas 2018.

Saputro, R. A., Idris, M., \& Suryani, I. (2020). Sejarah dan Budaya Palembang Barat sebagai Sumber Buku Saku Sejarah. Kalpataru: Jurnal Sejarah dan Pembelajaran Sejarah, 6(1), 6-17.

Sholeh, K. (2018, July). Masuknya Agama Islam di Palembang pada masa Kerajaan Sriwijaya abad VII Masehi. In Prosiding Seminar Nasional Program Pascasarjana Universitas Pgri Palembang (Vol. 5, No. 05).

Sulistyo, W. D. (2019). Study on Historical Sites: Pemanfaatan Situs Sejarah Masa Kolonial di Kota Batu sebagai Sumber Pembelajaran Berbasis Outdoor Learning. Indonesian Journal of Social Science Education (IJSSE), 1(2), 124-135. 